Article

\title{
Energy and Water Needs Analysis: Towards Solar Photovoltaic Water Pumping in Rural Areas of Malawi
}

\author{
Esther Phiri ${ }^{1,2, *}$, Ansley Kasambara ${ }^{3}$, Paul N. Rowley ${ }^{1}$, \\ Richard E. Blanchard ${ }^{1}$ \\ 1 Centre for Renewable Energy Systems Technology, Loughborough University, \\ Loughborough, LE11 3TU, UK \\ 2 Department of Electrical Engineering, University of Malawi-Polytechnic, P/Bag \\ 303, Blantyre, Malawi \\ 3 Mathematics and Statistics Department, University of Malawi-Polytechnic, \\ P/Bag 303, Blantyre, Malawi \\ * Correspondence: Esther Phiri, Email: ephiri@poly.ac.mw;
} Tel.: +265-995-500-085.

\begin{abstract}
Water and energy are both major challenges in rural areas of developing countries, including in the sub-Saharan Africa Region. This study assessed water and energy needs, challenges, and costs in order to produce a body of knowledge and further explore ways in which the water-energy synergies could be utilised. A mixed-mode survey method consisting of questionnaires, semi-structured interviews, observations and focus group discussions involving participants in the rural areas of Chiradzulu District in Malawi was employed. The study findings show that water access is generally inadequate, caused by high population, low yield, disparity in the distribution of water sources, and non-functionality. Using the contingent valuation method, logistic regression showed the only predictor of willingness to pay for drinking water was income and the predictors to pay for irrigation water were occupation, age and household size. Sustainable energy access was also found lacking for cooking and basic energy services such as for lighting, mobile charging and for radios. Biomass remains the main source of cooking energy, whereas battery powered torches have replaced paraffin for lighting. Overall, the household survey results imply that there is need for more sustainable water and energy provision. To address both challenges, the study recommends solar PV water pumping systems which can be designed in such a way that they can be simultaneously used for providing basic energy services. Further research is needed to address cooking energy choices.
\end{abstract}

\section{Open Access}

Received: 22 October 2019

Accepted: 26 February 2020

Published: 03 March 2020

Copyright (c) 2020 by the author(s). Licensee Hapres, London, United Kingdom. This is an open access article distributed under the terms and conditions of Creative Commons Attribution 4.0 International License.
KEYWORDS: energy access challenges; household; rural Malawi; solar PV water pumping; sub-Saharan Africa; sustainable energy; water access challenges; willingness to pay 


\section{ABBREVIATIONS}

PV, Photovoltaic; MDG, Millennium Development Goals; SDG, sustainable development goal; SSA, sub-Saharan Africa; RETs, renewable energy technologies; SE4All, Sustainable Energy for All; CVM, contingency valuation method; WTP, willingness to pay; WHO, World Health Organization; ATP, ability to pay; MDHS, Malawi Demographic and Health Survey; TA, traditional authorities; HSA, Health Surveillance Assistant; NGO, non-governmental organisation; VSL, Village Savings and Loan; SD, standard deviation; SPWP, solar photovoltaic water pumping; GoM, Government of Malawi

\section{INTRODUCTION}

There is an inter-linkage between energy and water supply systems which together present major global development challenges. Firstly, millions of people are without access to both clean water and energy services; secondly, both have rapidly growing demand; thirdly, both have interdependencies with climate change and the environment; and lastly, both have resource constraints [1]. Water and energy access problems are increasing due to a rapidly rising global population, growing prosperity and climate change, and by 2030 their demand is expected to rise by $30-50 \%$ [2]. Appropriate access to both services were essential for achieving the millennium developmental goals (MDGs), which have now been superseded by the Sustainable Development Goals (SDGs). In 2014, the number of households with sustainable access to improved water in Malawi was $86.2 \%$, exceeding the MDG target of $74 \%$ [3] and making it one of the few developing countries to attain its water target. However, even for those with improved drinking water access, the quality, usability, functionality and safety for most of the sources is questionable [4-7]. Specifically, this study aims to contribute towards SDG 6 on clean water and SDG 7 on access to energy. Benefits of water and modern energy services to human development in developing countries have been recognised in the literature. These include, among others, improved health, poverty alleviation, improved education, potential for income generating activities, gender equality, reduced drudgery on women and girls (which frees up time for productive and social uses), environmental sustainability, and improved agricultural outputs that enhance food security [8-11].

Safe drinking water reduces the incidences of diarrhoea and cholera [12], which are leading causes of child mortality. In rural areas of sub-Saharan Africa (SSA) (which includes Malawi), the burden of collecting water mainly falls on women and girls, which is associated with musculoskeletal disorders and related disabilities for women [13]. If the total time taken per round trip exceeds $30 \mathrm{~min}$, households tend to collect less water, thus compromising their water intake [14-16]. Water collection also negatively impacts education access, especially for girls, 
who may be late for school, may be absent, or may fail to concentrate in class because of fatigue caused by collecting water [13]. Additionally, teachers are more willing to be posted to rural schools where water is available [8]. Water availability empowers women and girls by providing water for their sanitary needs and improves their safety, dignity and confidence. In addition, sexual harassment or other violence to women that may take place when collecting water can be avoided [17,18].

Water used in irrigation has a positive impact on food security and poverty reduction, particularly in the face of climate variability [19,20]. More than $70 \%$ of Africa's poor people live in rural areas and mostly depend on agriculture for their livelihoods, but only about $6 \%$ of the total cultivated area is irrigated [21]. Malawi still relies on rain-fed agriculture, and because of persistent droughts and floods aggravated by climate change, there are insufficient harvests, which results in famine and worsens poverty [22]. In SSA, hand-pumps are widely used for domestic water abstraction but are non-functional up to $60 \%$ of the time [23]. Hand-pumps used on shallow wells are more easily contaminated than those on the deep wells, and in the dry season most shallow wells dry up [5]. Hand-pumps, treadle pumps and watering cans, which are commonly used for irrigation, are manually straining, and most of the treadle pumps have been abandoned [24]. Groundwater is available in SSA including in Malawi [25], where over 20\% of the country's area is water in the form of lakes and rivers. Electric-powered pumping systems could be used for water pumping, but like in other countries in SSA, Malawi's rural areas lack adequate grid electricity [26]. Fuel-powered systems have disadvantages such as vulnerability to oil prices, depletion of fossil fuels, pollution, noise, transportation and high maintenance costs [27]. Some motorised pumps were introduced by the Malawi Government and distributed freely to farmers, but most of them are no longer in use due to farmers' inability to meet fuel and maintenance costs [28,29]. Hence, renewable energy technologies (RETs) could provide a viable option and at the same time contribute towards the Sustainable Energy for All (SE4All) initiative's goals [30]. Motorised pumps, which require electricity or diesel generators for pumping water, could enhance water accessibility by allowing for deeper boreholes. With lack of grid electricity in most of the rural areas in Malawi and disadvantages from diesel as cited by other authors such as [27,31], Malawi has relatively high insolation, making solar photovoltaic (PV) water pumping (SPWP) a possible option. Studies have shown that groundwater resources of more than $20 \mathrm{~m}$ depth are less susceptible to drying up and less vulnerable to contamination, and therefore might not need treatment [32-34]. SPWP would make it possible to extract water from deeper wells that in a majority of cases would not need treatment. Hence, this study proposes the use of SPWP from deep aquifers, which has been practised in other countries to provide drinking and irrigation water [31,35,36]. Solar PV has been used in Malawi for pumping water but lacks documentation. 
According to Nixon Sinyiza (Nixon Sinyiza, Personal Communication, 25 November 2015), his NGO is one of the pioneers in the use of SPWP in Malawian rural communities. He reported that a complete basic water pumping system with one stand post and using solar modules, tanks, a solar motor-pump set and a water treatment system costs a minimum of US $\$ 25,000$ or more depending on the number of taps and whether it is a distributed system or not. Water is pumped into storage tanks at an elevation of up to 6 metres so as to redistribute the water using gravity. Mr Sinyiza further reported that his organisation has also piloted water kiosks in Malawi from which water is dispensed by an automated water distribution point that is integrated with a secure payment facility. In addition to water provision, the system incorporates charging ports for charging low power gadgets. However, he mentioned that it was too early to evaluate their technical performance.

One way to finance rural water supplies is to pay for water; however, it must be established if the people would be willing to pay, and how much. The contingency valuation method (CVM) is a popular means to determine willingness to pay (WTP) [27]. In the CVM individuals are asked hypothetical questions on how much they would be willing to pay to access a resource or goods [7]. CVM is implemented in one of two ways. The first is the open-ended method in which the respondents are directly asked to state their maximum WTP. The second is called the dichotomous choice, referendum or bidding game approach in which the respondent is asked whether he or she is willing to pay a specific amount of money and the question is repeated for a higher sum of money until the respondent settles on a maximum offered price.

This study used the open-ended approach, in which the respondents were asked how much they would be willing to pay for improved water in quality and quantity obtained using SPWP. The proposed water service was explained properly as suggested by [8]. The respondents were told that water would be from a tap closer to where they were staying rather than a handpump and would be of potable quality. With respect to quantity, they were told that the supply would not dry up and therefore would be readily available all the time to ensure that their daily requirements were met. In Malawi, water quantity and quality are as guided by WHO guidelines and/or the Malawi Bureau of Standards [9,10]. The World Health Organization (WHO) [10] defines access to water supply in terms of the types of technology and levels of service afforded. Access to basic water-supply services is the availability of at least $20 \mathrm{~L}$ per person per day from an "improved" source within $1 \mathrm{~km}$ of the user's dwelling. WHO classifies the following as improved drinking-water sources: (1) piped water into a dwelling, yard or plot; (2) a public tap or standpipe; (3) a tube well or borehole; (4) a protected dug well; (5) a protected spring; and (6) rainwater collection. WHO classifies the following as unimproved drinking-water sources: (1) an unprotected dug well; (2) an unprotected spring; (3) a cart with a small tank or drum 
provided by a water vendor; (4) a tanker truck providing water; (5) surface water (e.g., a river, dam, lake, pond, stream, canal, or irrigation channel); and (6) bottled water. The respondents were already in a position in which they were actually paying for water and therefore recognized the implication of the scenario under consideration. Further, the CVM was complemented by focus group discussions as a way to minimise bias [11].

Factors that influence a household's willingness to pay for an improved water supply are the socioeconomic and demographic characteristics of the household, income level, expenditures, assets, size and composition of the family, occupation, gender, level of education and cost. Other factors influencing the household's willingness to pay are: the characteristics of the existing or traditional source of water compared to those of the improved water supply such as perceived quality and reliability, and households' attitudes toward government policy in the water supply sector, and the households' sense of entitlement to government services [37,38]. Affordability or ability to pay (ATP) for water is determined by the ratio of the amount paid for water to income. An ATP of $5 \%$ is generally assumed to be the maximum acceptable ATP that a household should pay for water.

Research in Malawi has investigated water quality [5,39], groundwater availability [40,41], water management [42], and the relationship of water to disease [43]. Some of the available studies showed that boreholes or shallow wells in the rural areas of Malawi often produced contaminated water and/or dried up in the dry season. A borehole is defined as "a hole in the ground that has been drilled by mechanical or manual means for the purpose of abstracting water" [44]. In Malawi, boreholes also known as deep wells have a recommended minimum depth of $20 \mathrm{~m}$, with most of the deep boreholes in the range of 20 to $60 \mathrm{~m}$, with an average of $45 \mathrm{~m}$. Those less than $20 \mathrm{~m}$ are referred to as shallow wells, which is consistent with relevant literature [44,45]. Deep wells and protected shallow wells are considered to be improved sources, and both may be fitted with a handpump [5]. These similarities make it difficult to differentiate between the two, and therefore both are referred to as borehole or handpump by the locals.

Literature for SSA and Malawi showed that the community-based model for water provision in the rural areas had failed to ensure the functionality of water sources [46-48]. There is limited discussion of water access and willingness to pay for water in the literature, particularly for rural households in Malawi. On the other hand, data on energy access is mostly available at the national level in census reports and the Malawi Demographic and Health Survey (MDHS) reports, with limited data for the household and district levels [49,50]. The energy access component was carried out to assess the households' energy access types, costs, challenges and opportunities. It was included to evaluate possible synergies with using solar PV for additional purposes 
other than just the provision of water. The literature shows that phone and lantern charging is a viable business in the rural areas of developing countries [51,52]. With no grid connection, solar PV makes an attractive source of electric power to provide these basic energy needs.

This study was carried out to understand in detail household water and energy contexts in the rural areas of Malawi. The study had the following specific objectives: (a) to analyse the water and energy usage and requirements of rural households; (b) to determine the water and energy-related challenges experienced by rural households; (c) to establish the willingness to pay (WTP) and factors that predict the WTP for water; and (d) to explore sustainable solutions to the water and energy challenges.

\section{MATERIALS AND METHODS}

\section{Context of Study Area}

The study was carried out in Chiradzulu, which is one of the 28 districts in Malawi, in August-September 2015. Malawi lies between latitudes $9^{\circ} 22^{\prime} \mathrm{S}$ and $17^{\circ} 03^{\prime} \mathrm{S}$ and longitudes $33^{\circ} 40^{\prime} \mathrm{E}$ and $35^{\circ} 55^{\prime} \mathrm{E}$. It is a landlocked country, has a total area of $118,480 \mathrm{~km}^{2}$, and is approximately $900 \mathrm{~km}$ long, with a maximum width of approximately $250 \mathrm{~km}$. Lake Malawi has fresh water and is the third largest in Africa. With the addition of a few other smaller lakes and many rivers and streams, Malawi has abundant freshwater resources that take up approximately $20 \%$ of the country's area [53]. In 2015, the population was estimated at 17.22 million. Over $80 \%$ of the population lives in the rural areas, whereas the rest $(<20 \%)$ lives in urban areas [54]. Chiradzulu district area is $767 \mathrm{~km}^{2}$ and is divided into 6 traditional authorities (TAs). It has approximately 787 villages and a population estimated at over 390,000 [55].

\section{Sampling}

A mixed-mode survey method consisting of questionnaires, semi-structured interviews, observations and focus group discussions (FGDs) was employed [56,57]. The quantitative methodology was dominant, and semi-structured interviews, observations and FGDs provided for triangulation and validity [58]. Multi-stage cluster sampling, particularly the "30 by 7" two stage cluster sample method developed by WHO, was adapted for this study [59]. Hence, 30 villages were sampled with a minimum of seven households per village. This method was utilized because of its simplicity and applicability in populations where a listing of all eligible individuals is not available for sampling purposes [56,58]. Also, it was more efficient in terms of costs, transportation and time [60]. Ethical considerations approval was gained from both Loughborough University and from the Malawi National Commission for Science and Technology. The district commissioner was notified about 
the study. On the ground, Health Surveillance Assistants (HSAs) based at the health-care centres within the district were identified as the gatekeepers who guided the research team to the villages through the village heads.

\section{Data Collection}

A questionnaire was developed with reference to previous studies [38,61-63]. The first section sought information on the household's socio-economic characteristics such as size of household, income, expenditures, and employment status. The second section was on water access and sought to know about sources of drinking water, quantity collected, challenges, and WTP for both drinking water and water for agriculture. The third section was on energy access and asked about sources of energy, challenges, current cost of energy, aspired businesses, and WTP for the reported energy needs. The questionnaire was written in English and translated to Chichewa (the local language). A pilot study was carried out in one of the villages in the study district. The questionnaires were administered face-to-face by five research assistants who were all fluent in Chichewa and English. Participants were those living in the rural areas. The household was the unit of analysis, and the preferred respondent was the household head. In some cases, the male heads referred questions about how long it takes to collect water/firewood and how much water is collected to their wives and/or children, who were more conversant with such issues. The rest of the questions were answered by the household head.

For FGDs, arrangements were made with the village head through the HSA to assemble the group for the following day's discussion. In total, four FGDs from four villages were conducted as follows: (1) one males only group with eight participants; (2) one females only group with nine participants; (3) one male and female combination group with 15 participants; and (4) one Water-point Committee group consisting of males and females with eight participants. On average, the FGDs lasted 45 minutes. As the FGDs complemented the questionnaire, guide questions were designed to be similar to the household survey questions. The discussions were captured using a voice recorder and note-taking. An introductory in-depth, semi-structured interview was held with the village head and HSA to get the background information for each village, including both available facilities and aspired facilities. Direct observations were made throughout the data collection period and captured using photographs and written notes.

\section{Data Analysis}

A pie chart was used to summarise the results for the time taken to make a round trip to collect water, the number of times water is collected in a day and the reasons for not treating water. Histograms were used to summarise water consumption, challenges faced with the current water 
sources, willingness to pay for drinking and agriculture water and energy sources in use.

Further analysis was done through cross-tabulations and chi-square tests between categories (derived from the median) of amounts that respondents were willing to pay for drinking water ( $\$ 0$ to $\$ 0.38$ and $\$ 0.39$ to $\$ 13.46$ ) and gender, age groups, marital status, highest education qualification, occupation, household size (in two categories) and four income groups. Similar analysis was also completed for the amounts that respondents were willing to pay for water for agriculture (\$0 to $\$ 0.66$ and $\$ 0.67$ to $\$ 15.38$ ).

A logistic regression was performed to assess the effects of gender, age, marital status, highest education qualification, income, household size, occupation and litres collected on the likelihood that individuals were willing to pay $\$ 0.39$ or more for drinking water. Another logistic regression was performed to assess the effects of similar variables on the likelihood that individuals were willing to pay $\$ 0.67$ or more for water for agriculture.

\section{RESULTS}

\section{Socio-Economic Characteristics}

The questionnaire was administered to household heads (or their representatives) from 30 selected rural villages pooled from all six TAs of Chiradzulu District. The demographic characteristics of the households are summarised in Table 1. In total, 219 valid responses were obtained. The mean household size was 4.8 people. There were more male-headed households ( $n=160$, or $73.1 \%$ ) than female-headed ones ( $n=59$, or $26.9 \%$ ). Most of the female heads were not married (single, widowed, or divorced) ( $n=52$ or $23.74 \%$ ), whereas only one $(0.46 \%)$ of males was not married. The educational qualifications showed that more than a fifth $(n=47$ or $21.5 \%)$ of the respondents was illiterate whilst less than a fifth $(n=39$ or $17.8 \%$ ) had 12 years of education or more. Males were more educated than females; for instance, only two females $(0.91 \%)$ had 10 or more years of education as compared to 37 males (17\%). The main occupation of the household head was subsistence farming (60\%). Over a quarter (26\%) were involved in small business such as selling farm produce, livestock, sugarcane, horticultural crops traditional snacks, traditional beer, and running small shops. Several others (16\%) were involved in casual labour, which included menial work in their villages and in the surrounding areas. A few (7\%) were in full-time employment as teachers, health centre staff or as guards in the nearby city of Blantyre. The rest (4\%) depended on gifts and remittances.

The income and expenditure quartiles illustrate the households' low incomes; with 55 households (25\%) having a monthly income of approximately US $\$ 8$ and only another 55 households (25\%) having a monthly income of more than US $\$ 30$, which translated to approximately 
US\$1 per household per day. However, these figures may not reflect actual income because some of the day-to-day transactions of households are not in form of money. For households with irregular incomes, their monthly income was estimated from annual produce sales, business sales or casual labour engagements. A Mann Whitney U test to compare the income levels of the males and females showed a statistically significant difference ( $p=0.047$ ), with males having more income than women. Only 13 households (5.9\%) had bank accounts, and from the FGDs it was reported that several belonged to Village Savings and Loans (VSL) groups.

Table 1. Demographic data of the Chiradzulu rural households' survey.

\begin{tabular}{|c|c|c|c|}
\hline Demographic characteristic & Variable & Count & Percent \\
\hline \multirow[t]{2}{*}{ Parameter } & No of villages & 30 & 100 \\
\hline & No of Respondents (Household Heads) & 219 & 100 \\
\hline \multirow{2}{*}{$\begin{array}{l}\text { Gender of Head of Household (or } \\
\text { Respondent) }\end{array}$} & Male & 160 & 73 \\
\hline & Female & 59 & 27 \\
\hline \multirow[t]{4}{*}{ Age of Household Head } & 16 to 20 years & 5 & 2.3 \\
\hline & 21 to 59 years & 168 & 76.7 \\
\hline & 60 and above & 40 & 18.3 \\
\hline & Don’t Know & 6 & 2.7 \\
\hline \multirow[t]{6}{*}{ Highest Educational Qualification } & Illiterate & 47 & 21.5 \\
\hline & Read \& write & 97 & 44.2 \\
\hline & PSLCE (Yr8) & 36 & 16.4 \\
\hline & JCE (Yr10) & 19 & 8.7 \\
\hline & MSCE (Yr12) & 19 & 8.7 \\
\hline & Tertiary & 1 & 0.5 \\
\hline \multirow[t]{4}{*}{ Household Size } & 1-2 people & 22 & 10.0 \\
\hline & 3-5 people & 125 & 57.1 \\
\hline & $>6$ people & 72 & 32.9 \\
\hline & Mean Household Size & 4.8 & \\
\hline \multirow[t]{6}{*}{ Occupation } & Subsistence farming & 83 & 37.9 \\
\hline & Small business & 59 & 26.9 \\
\hline & Casual labour & 35 & 16.0 \\
\hline & Commercial Farming & 18 & 8.2 \\
\hline & Employed & 16 & 7.3 \\
\hline & Remittances/gifts & 8 & 3.6 \\
\hline \multirow[t]{9}{*}{ Household Asset Ownership } & Land & 157 & 71.7 \\
\hline & Mobile Phone & 127 & 58.0 \\
\hline & Radio & 99 & 45.2 \\
\hline & Bicycle & 98 & 44.7 \\
\hline & Solar Home System & 14 & 6.39 \\
\hline & Bank Account & 13 & 5.9 \\
\hline & $\mathrm{TV}$ & 13 & 5.9 \\
\hline & Treadle Pump & 6 & 2.7 \\
\hline & Motor Vehicle & 2 & 0.9 \\
\hline
\end{tabular}




\section{Drinking Water Access}

Table 2 summarizes the results of the water-related questions, which are thereafter discussed.

Table 2. Summary of water-related results.

\begin{tabular}{|c|c|c|c|}
\hline Drinking Water Parameter & Variable & Count & Percent \\
\hline \multirow[t]{3}{*}{ Water Source } & Handpump & 199 & 91 \\
\hline & Unprotected sources & 13 & 6 \\
\hline & Other & 7 & 3 \\
\hline \multirow[t]{3}{*}{ Who collects water } & Women & 175 & 80 \\
\hline & Girls & 41 & 19 \\
\hline & Males & 3 & 1 \\
\hline \multirow[t]{4}{*}{ How many times is water collected } & More than four times per day & 125 & 57 \\
\hline & Thrice per day & 64 & 29 \\
\hline & Twice per day & 26 & 12 \\
\hline & Once or less per day & 4 & 2 \\
\hline \multirow[t]{3}{*}{ Time taken to collect water } & 30 min or longer & 138 & 63 \\
\hline & Less than $30 \mathrm{~min}$ & 70 & 32 \\
\hline & Do not know & 11 & 5 \\
\hline \multirow[t]{2}{*}{ Is water enough } & Enough & 166 & 76 \\
\hline & Not enough & 53 & 24 \\
\hline \multirow[t]{3}{*}{ Water Treatment method } & Do not treat & 174 & 79 \\
\hline & Chlorination method & 40 & 18 \\
\hline & Boiling & 5 & 2 \\
\hline \multirow[t]{4}{*}{ Reasons for not treating water } & Water is safe & 131 & 60 \\
\hline & Water treatment is expensive & 48 & 22 \\
\hline & We are used to it & 26 & 12 \\
\hline & Other & 13 & 6 \\
\hline
\end{tabular}

Main source of drinking water

The main source of drinking water for the majority of households ( $n=199$, or $90.87 \%)$ was boreholes, which are classified as improved sources, whilst 13 households (6\%) collected drinking water from unimproved sources (i.e., rivers and unprotected wells and springs). The remaining households collected from gravity fed systems and protected springs and wells. Results from interviews with village heads and from FGDs showed that in many instances the number of people being served by a single water source exceeded the recommended number. For instance, the borehole at one of the villages was serving 191 households, which is almost four times the limit of 50 households per borehole as recommended by Government regulations. For other villages, the water sources were nearly adequate. For example, one village had five water sources supplying 280 households, averaging 56 households per water source. From the FGDs, one of the reasons reported why some villages 
had more water sources was that Members of Parliament for the particular areas lobbied or provided for more water sources.

\section{Who collects water and time taken to collect water?}

The results of the survey show that water was collected by 175 women (79.9\%), 41 girls (aged 15 years and below) (18.7\%) and only three (1.4\%) males. The women and girls carried the water on their heads in $20-40 \mathrm{~L}$ buckets. Figure 1 shows that nearly three fifths of the households $(n=125$, or 57\%) collected water more than four times per day. Figure 2 shows that over two thirds of households ( $n=130$, or $63 \%$ ) exceed 30 minutes per round trip of water collection. Nearly a fifth $(n=42$, or $19.2 \%)$ of the households reported that children had been late or absent from school because of water collection.

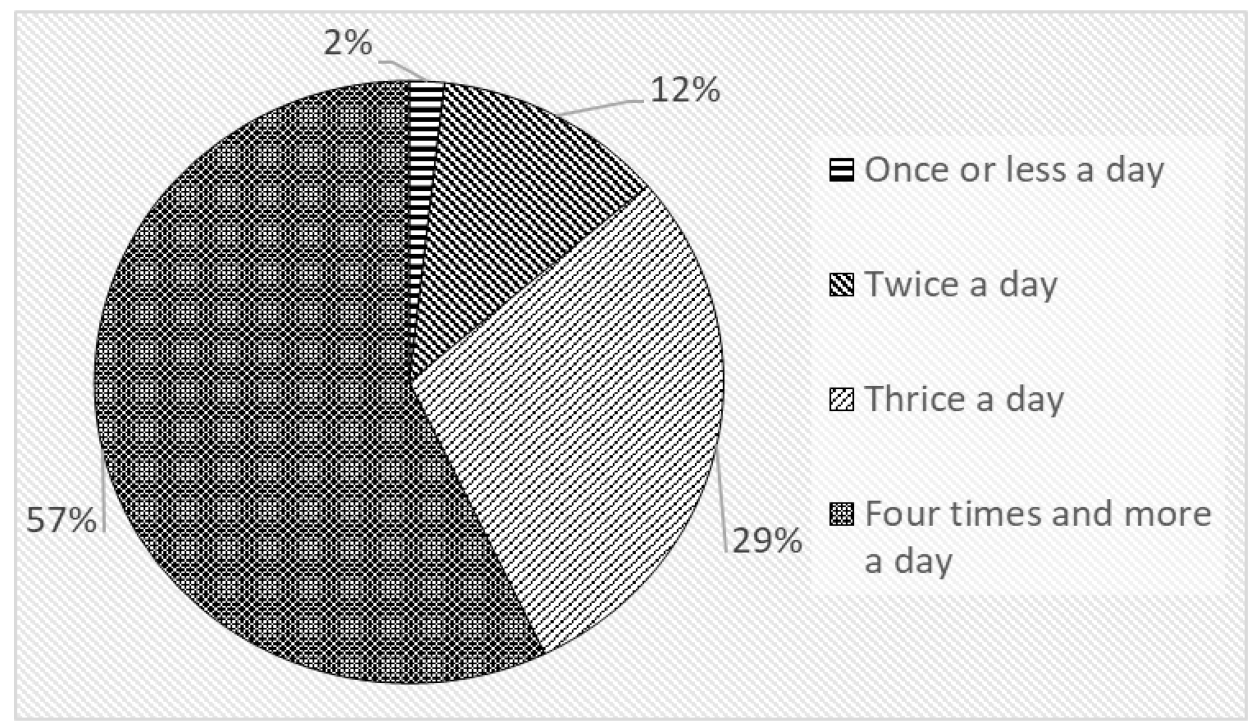

Figure 1. Number of times water is collected in a day.

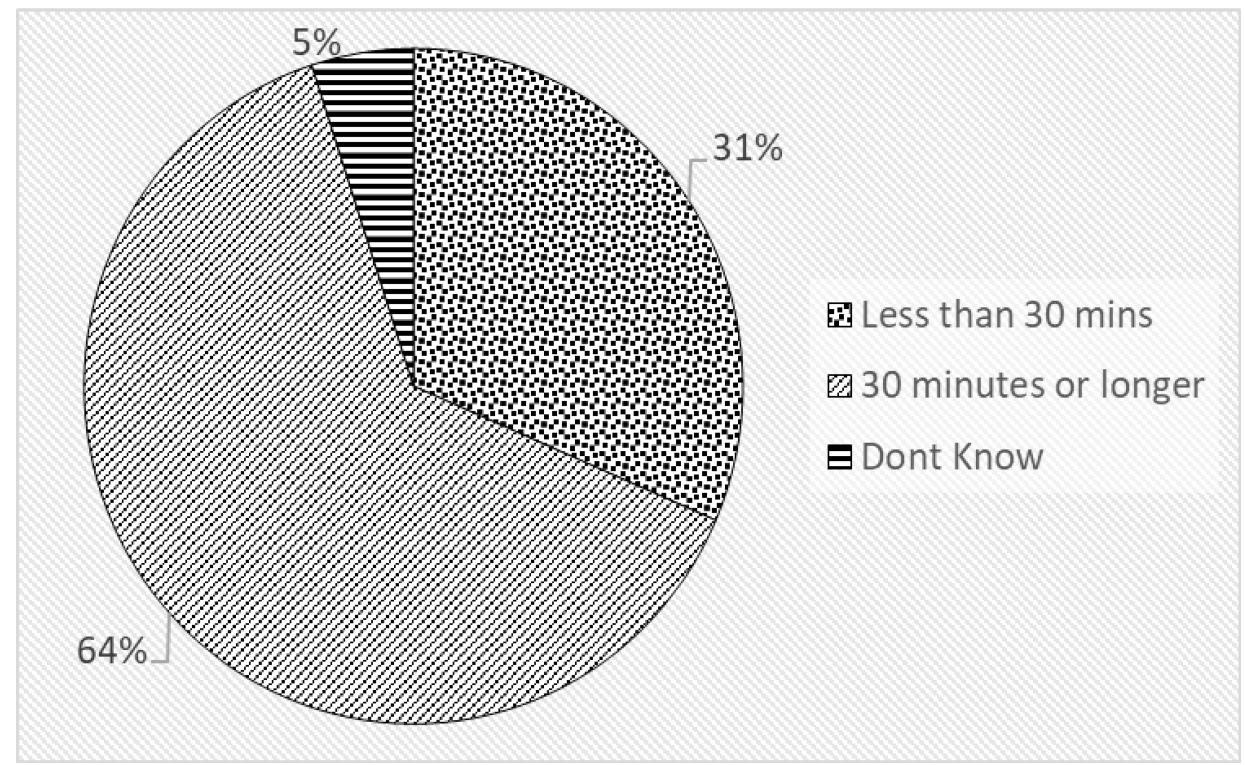

Figure 2. Time taken for round trip to collect water. 


\section{Water quantity, storage and household management}

The median amount of water collected was $120 \mathrm{~L}$ per household per day, which translated into approximately $25 \mathrm{~L}$ per person per day. The amount of water used specifically for income generating activities was not explicitly investigated. The histogram in Figure 3 shows the number of households and consumption of water by each household per day. Households that were engaged in home-based income generating activities required large quantities of water, especially those whose representatives mentioned beer-brewing as their source of income. Such families used up to half a tonne of water per household per day, which explains the outliers. All the households reported that they stored their drinking water in covered containers (i.e., buckets, jerry cans, clay pots), whereas water for other domestic purposes could be left uncovered. Spot checks by the research assistants verified these reports to be accurate. Of the respondents, $166(75.8 \%)$ reported that water from their current water source was enough. The rest ( $n=53$, or $24.2 \%$ ) thought water for their households was not enough. These households gave the following reasons for the insufficiency: (1) 40 (18.26\%) cited high population; (2) 9 (4.1\%) cited few collecting buckets; and (3) 4 (1.8\%) cited a long distance to collecting water. Most of the respondents $(n=190$, or 87\%) wished for an increase in the number of water sources and one $(0.5 \%)$ wished for improved information on available water treatment methods.

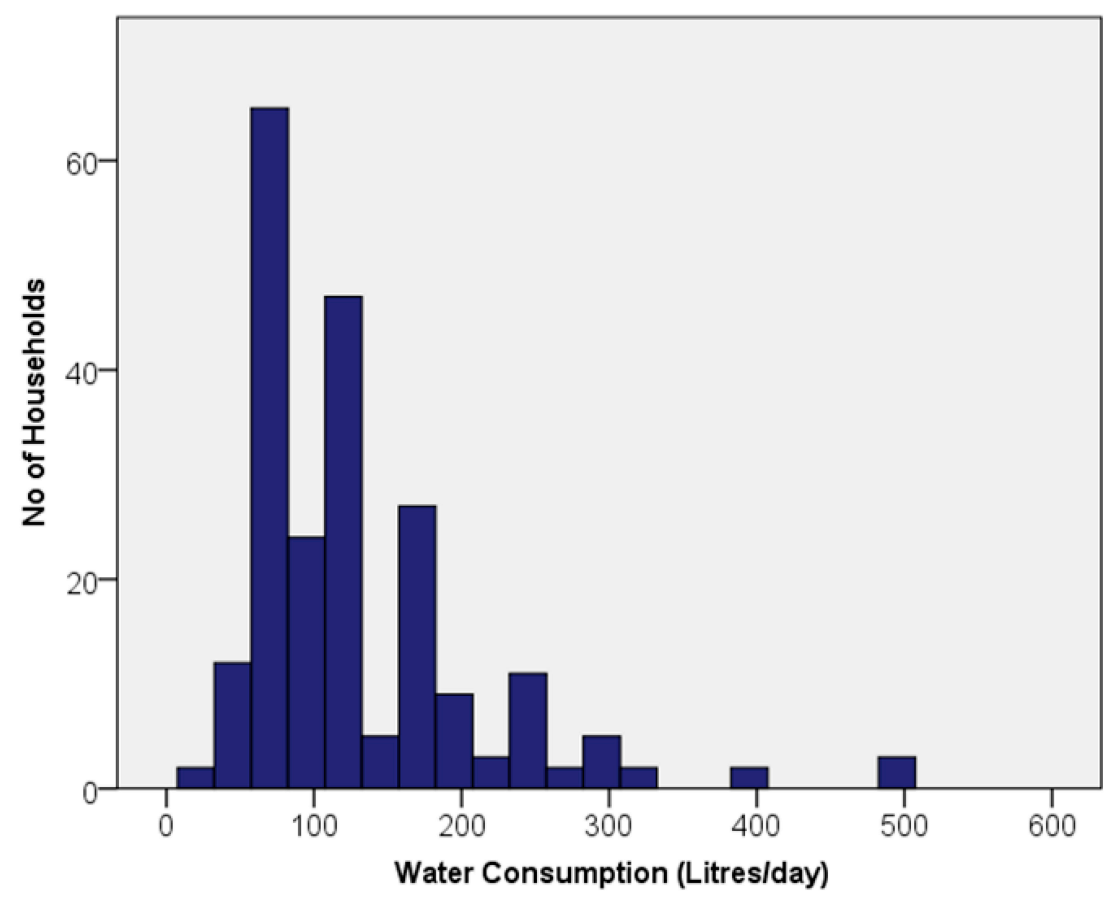

Figure 3. Number of households and their water consumption per day.

\section{Queuing and low yield}

Results on the challenges experienced by households on a 5-point Likert scale are as illustrated in the stacked chart of Figure 4 . The leading 
challenge in the provision of water was queuing. One such queue is shown in Figure 5. According to the FGDs, one reason for queuing was disjunction between the increasing population and the static number of boreholes, which meant that the population was outgrowing the capacity of the available boreholes. Queuing was also a result of low yield, which appears as the second challenge reported in Figure 5. Low yield was a challenge especially in the dry season. For instance, at one of the boreholes, the households waited until the afternoon for the borehole to produce water. They stated that the borehole was shallow, and the handpump was fitted on a hand-dug well. The other reason for queuing was the non-functionality discussed in the next section. Sexual assault during water collection was not reported, and from observation this was because the water sources were mostly within the villages.

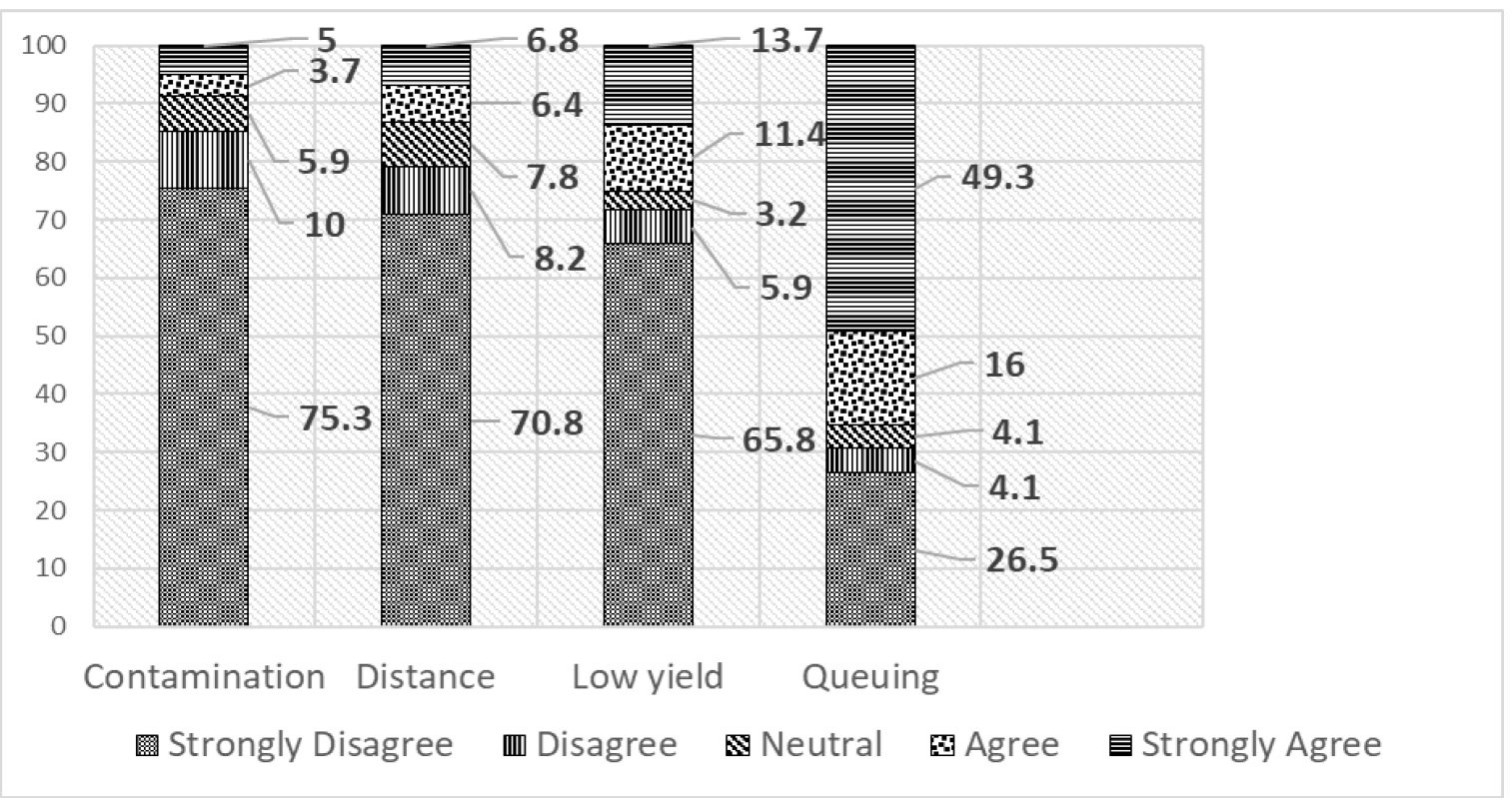

Figure 4. Households perception on severity of challenges, $n=219$.

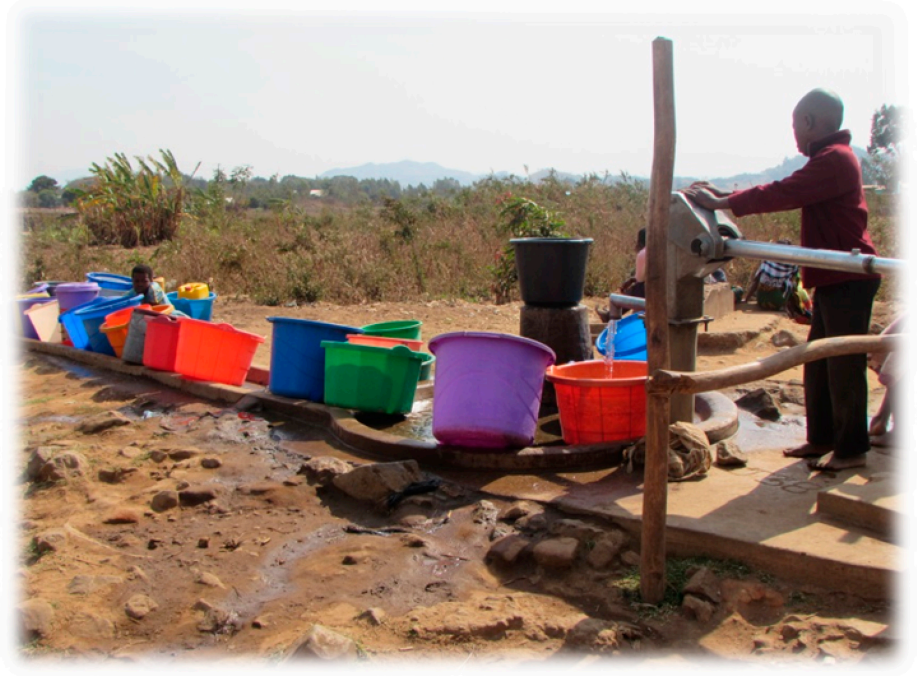

Figure 5. Queuing for water. 


\section{Water quality}

The majority of the respondents ( $n=174$, or $79.4 \%)$ did not treat their water, 40 (18.4\%) used the chlorination method and 5 (2.2\%) boiled their water. Figure 6 shows the reasons provided for not treating their water. Reasons in the "other" category included "HSA did not distribute chlorine" and "Do not know where to buy chlorine". Some households reported that they treat their water only in the rainy season. The village heads and HSAs indicated that they carry out health awareness meetings in the villages on a regular basis to discuss water management issues.

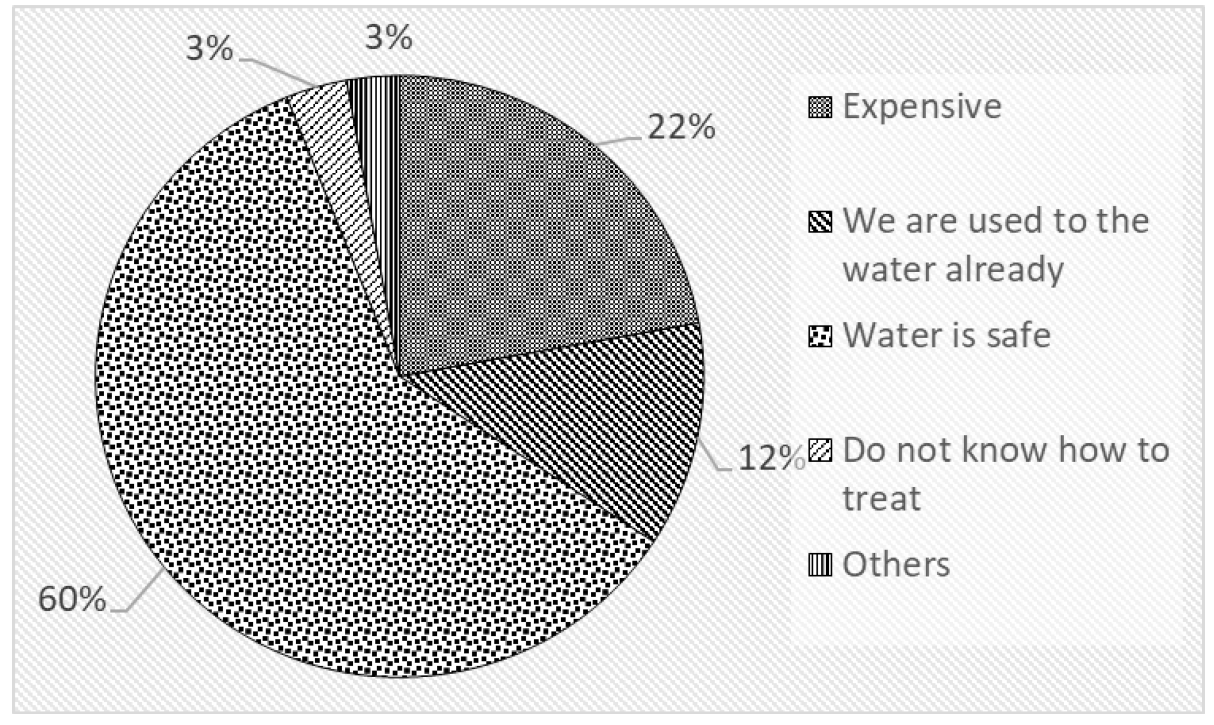

Figure 6. Reasons for not treating water.

Nearly a fifth of households ( $n=41$, or $19 \%$ ) reported experiencing an incidence of diarrhoea in the six months prior to the household survey. The survey was conducted in August and September, roughly six months after the dry season. Hence the incidences of diarrhoea might have been less than in the wet season. In the wet season, the contaminants are mobile, which means that diarrhoea is likely to be more frequent. From Figure 4, contamination of drinking water was reported to be a challenge by approximately $10 \%$ of households. During FGDs, the participants affirmed that children did get sick from diarrhoea. According to the village heads, diarrhoea was observed to be declining because of vigilant health campaigns by the district health office through the HSAs. In the FGDs, participants stated that the taste of the water was generally good. Turbidity was reported to be a common problem in the rainy season. Salinity was reported to be a problem by a few of the people. From observation, a borehole at one village was abandoned reportedly because of salinity. Saline water was also reported at one other village.

\section{Non-functionality and theft}

From the village head interviews, FGDs and observation it was established that non-functionality of boreholes was another challenge. 
For instance, in one of the villages, three out of the four boreholes were not functioning. Figure 7 shows women collecting water from a broken elephant pump at one of the villages, which puts the women at risk of falling. Non-functionality was caused by the failure to maintain the system by the community after normal wear and tear or after the borehole parts had been stolen. Theft and vandalism of borehole parts was reported to be widespread in the district. Theft extended to other items such as livestock, farm produce and household items. To curb the theft of borehole parts, some villages have placed chains and locks and sometimes concrete blocks over the hand-pumps as shown in Figure 8. In the FGDs, participants reported that the police were not vigilant and frequently released the suspects without charge. In the event that a borehole was not working or there was queuing, the households reported getting water from neighbouring villages, which in many cases were further away, which caused overcrowding. The women are usually met with hostility, resulting in scrambling and quarrels. As an alternative, the women collected water at night or from unprotected sources such as nearby rivers or streams.

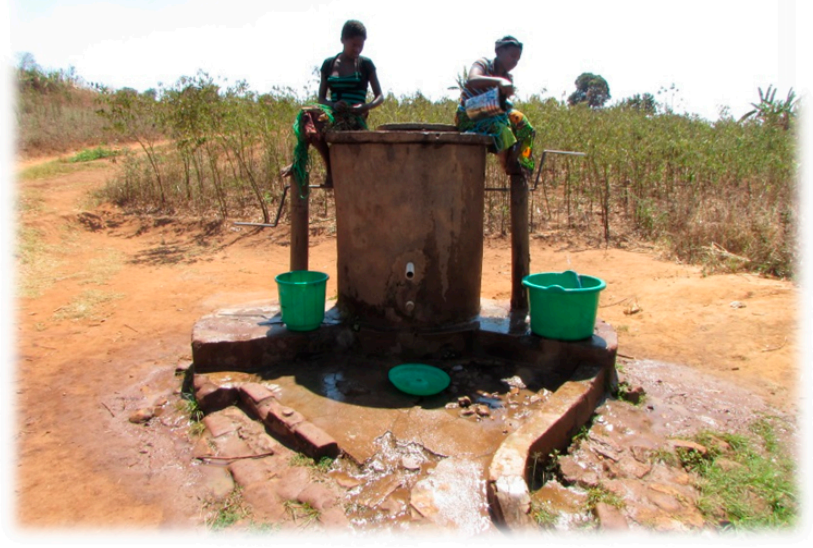

Figure 7. Women collecting water from a broken elephant pump.

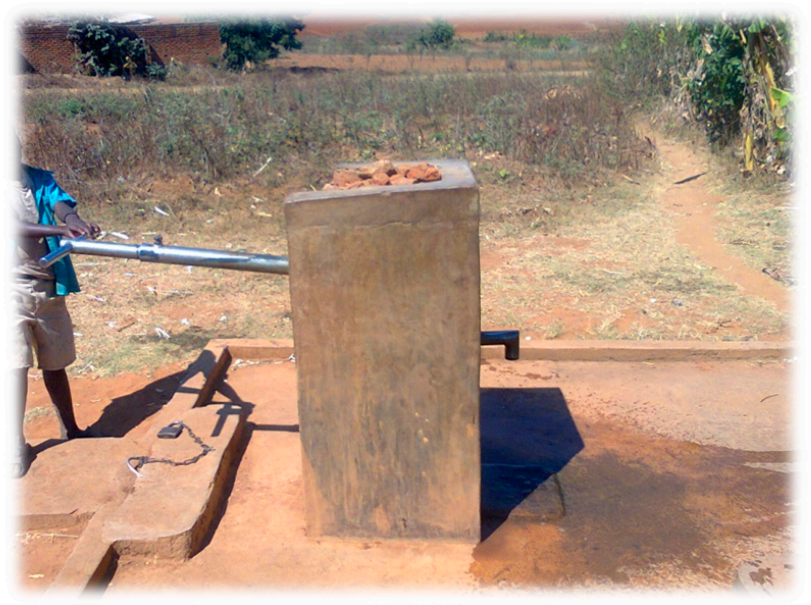

Figure 8. Concrete block built over handpump and chain and lock to protect from theft. 


\section{Water for irrigation}

In the FGDs, participants reported that most of the households relied on rain-fed agriculture. A few households practiced traditional irrigation methods on small pieces of land that were close to rivers, streams or wetlands. Reported methods of water abstraction were watering cans/buckets and treadle pumps, with only six (1.4\%) of the households owning a treadle pump. The participants reported that the irrigation methods were labour intensive, limited the amount of land that could be planted and hindered others from practicing irrigation. Smaller livestock were watered from the same sources used for drinking. Larger livestock drank from rivers and streams. According to participants in the FGDs, the factors affecting take-up of irrigation practice included the availability of land close to water, type of soil, market availability and accessibility and availability of farm inputs.

\section{Willingness and Ability to Pay for Water}

\section{Willingness to pay for water}

The respondents were asked how much they would be willing to pay for improved water in quality and quantity obtained using SPWP, which means that it would be readily available all the time. The findings show that the majority of the households ( $n=208$, or 95\%) were willing to pay for drinking water. Those that were unwilling reported that they were too poor/old to pay or had their own source of water. In terms of irrigation water, the results show that if households were to have easily accessible irrigation water, 160 (73\%) of the households were willing to pay. Table 3 shows the monthly amount of money they are currently paying for drinking water, together with the WTP amount for drinking and irrigation water respectively. Malawian currency is the Malawi Kwacha (MWK), and at the beginning of the data collection phase, MWK520 was equivalent to US $\$ 1$. The income and water consumption are included for perspective. Complementing Table 1, histograms in Figure 9 and Figure 10 illustrate the difference between WTP amounts in US\$ for drinking water and for irrigation water.

Table 3. Income, current contribution, WTP for water and amount of water collected.

\begin{tabular}{lllllll}
\hline Variable & $\boldsymbol{N}$ & Mean & Median & SD & Minimum & Maximum \\
\hline Income (US\$/month) & 210 & 27.74 & 14.98 & 34.39 & 0.33 & 195.23 \\
Consumption (litres/day) & 219 & 130.50 & 120.00 & 81.51 & 20.00 & 500.00 \\
Current Drinking Payment (US\$/month) & 201 & 0.29 & 0.19 & 0.20 & 0.04 & 0.96 \\
WTP Drinking (US\$/month) & 207 & 1.08 & 0.38 & 1.85 & 0.10 & 13.46 \\
WTP Irrigation (US\$/month) & 159 & 1.99 & 0.96 & 2.64 & 0.10 & 15.38 \\
\hline
\end{tabular}




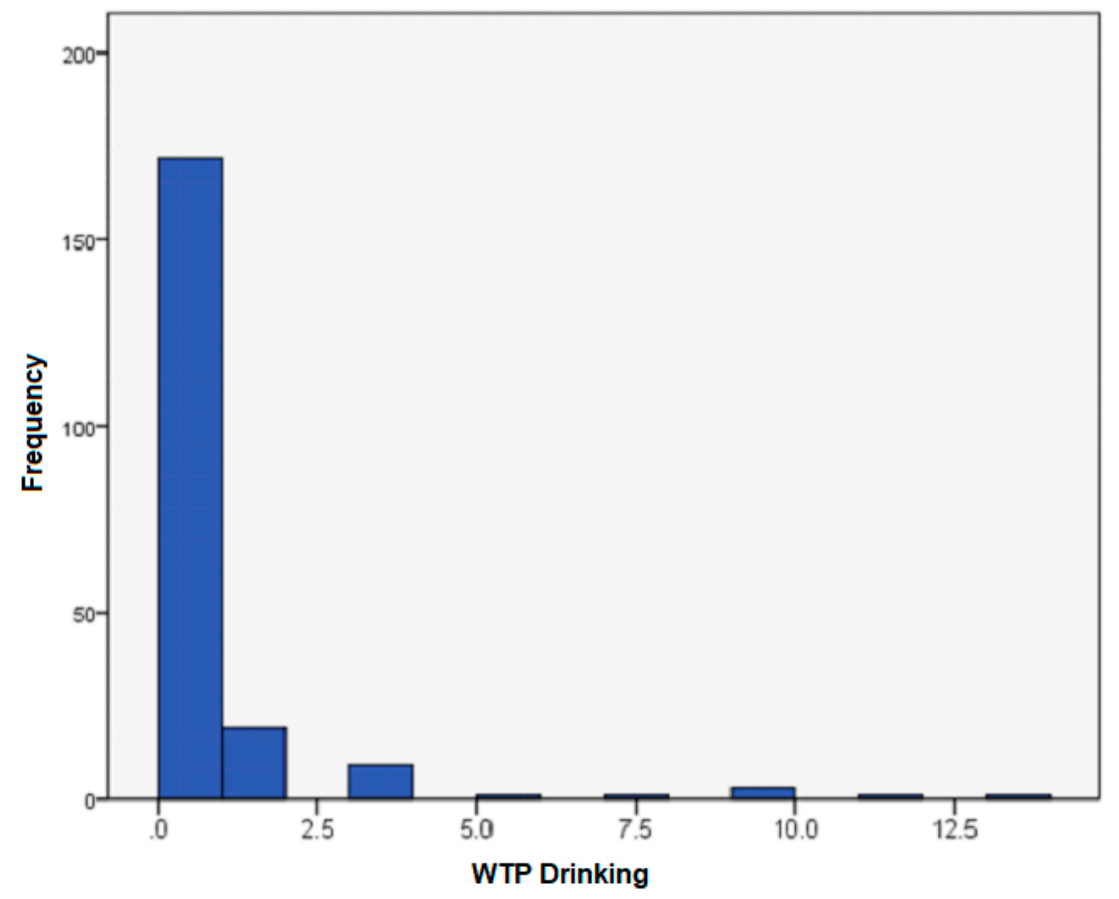

Figure 9. Histogram illustrating the WTP for drinking water.

There are outliers on willingness to pay because some respondents were employed as teachers or health centre staff and had high incomes, hence were willing to pay more for water.

In the FGDs, the households' consensus was for monthly payments, although a few proposed paying per bucket. For both drinking and irrigation water, participants in the FGDs indicated that they were willing to reconsider their WTP after being presented with an actual invitation.

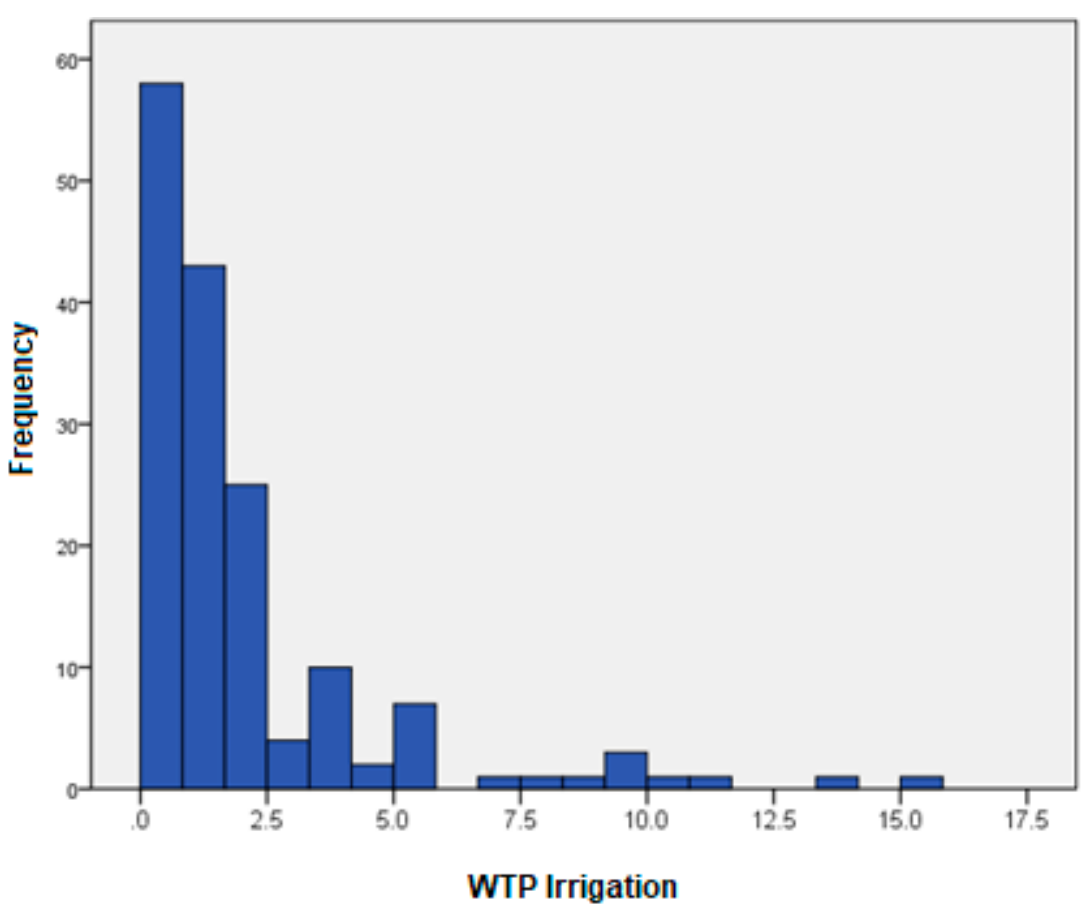

Figure 10. Histogram illustrating the WTP for irrigation water. 
Relationship between willingness to pay for drinking water and demographic variables

Table 4 shows cross-tabulation results for the relationship between willingness to pay for drinking water and the variables of gender, age group, marital status, highest education qualification, income group, household size, occupation and quantity of water collected.

The Chi square test of association summarised in Table 5 showed that there is a relationship between highest education qualification and willingness to pay for drinking water (Chi-square $=14.504, p$-value $=$ 0.013), as well as between occupation and willingness to pay for drinking water $($ Chi-square $=13.476, p$-value $=0.019)$. However, there were no significant associations between willingness to pay and gender, age group, marital status, household size or income group.

A logistic regression was performed to assess the effects of gender, age, marital status, highest education qualification, income, household size, occupation and litres collected (the independent variables) on the likelihood that individuals were willing to pay $\$ 0.39$ or more for drinking water (the dependent variable). None of the variables had a significant effect on willingness to pay for water except for income (Chi-square = $8.457, p$-value $=0.004$ ). The model only explained $5.3 \%$ of the variation in willingness to pay and correctly classified $57.1 \%$ of the cases. These results show that an increase in income was associated with an increase in the likelihood of willingness to pay between $\$ 0.39$ and $\$ 13.46$ for drinking water.

Table 4. Relationship between willingness to pay for drinking water and demographic variables.

\begin{tabular}{llllll}
\hline \multirow{2}{*}{$\begin{array}{l}\text { Demographic } \\
\text { Characteristic }\end{array}$} & Variable & \multicolumn{3}{l}{ Amount Willing to Pay for Drinking Water (USD) } \\
\cline { 3 - 6 } & & $\mathbf{0}$ up to $\mathbf{0 . 3 8}$ & \multicolumn{2}{c}{$\mathbf{0 . 3 9}$ up to 13.46 } \\
\cline { 3 - 6 } Gender & Male & 83 & 37.9 & 77 & \% of Total \\
\hline & Female & 38 & 17.4 & 21 & 9.6 \\
\hline Age Group & 16 to 21 years & 2 & 0.9 & 3 & 1.4 \\
& 22 to 59 years & 89 & 41.8 & 79 & 37.1 \\
& 60 and above & 27 & 12.7 & 13 & 6.1 \\
\hline Marital Status & Single & 2 & 0.9 & 2 & 0.9 \\
& Married & 85 & 38.8 & 81 & 37.0 \\
& Separated & 1 & 0.5 & 3 & 1.4 \\
& Divorced & 12 & 5.5 & 0 & 0 \\
& Widowed & 21 & 9.6 & 12 & 5.5 \\
\hline \multirow{2}{*}{ Highest } & Illiterate & 36 & 16.4 & 11 & 5.0 \\
Education & Read \& write & 47 & 21.5 & 50 & 22.8 \\
Qualification & PSLCE (Yr8) & 21 & 9.6 & 15 & 6.8 \\
& JCE (Yr10) & 7 & 3.2 & 12 & 5.5 \\
& MSCE (Yr12) & 10 & 4.6 & 9 & 4.1 \\
& Tertiary & 0 & 0.0 & 1 & 0.5 \\
\hline
\end{tabular}


Table 4. Cont.

\begin{tabular}{llllll}
\hline \multirow{2}{*}{$\begin{array}{l}\text { Demographic } \\
\text { Characteristic }\end{array}$} & Variable & \multicolumn{3}{l}{ Amount Willing to Pay for Drinking Water (USD) } \\
\cline { 3 - 6 } & & $\mathbf{0}$ up to 0.38 & \multicolumn{3}{c}{$\mathbf{0 . 3 9}$ up to 13.46 } \\
\cline { 2 - 6 } & & Count & \% of Total & Count & \% of Total \\
\hline \multirow{2}{*}{ Household Size } & Less than 6 & 93 & 42.5 & 79 & 36.1 \\
& More than 6 & 28 & 12.8 & 19 & 8.7 \\
\hline Income Group & 1 & 49 & 22.4 & 29 & 13.2 \\
& 2 & 15 & 6.8 & 19 & 8.7 \\
& 3 & 37 & 16.9 & 31 & 14.2 \\
& 4 & 14 & 6.4 & 25 & 11.4 \\
\hline Occupation & Subsistence Farming & 54 & 24.7 & 29 & 13.2 \\
& Commercial Farming & 9 & 4.1 & 9 & 4.1 \\
& Small Business & 24 & 11.0 & 34 & 15.5 \\
& Employed & 6 & 2.7 & 9 & 4.1 \\
& Casual Labour & 20 & 9.1 & 16 & 7.3 \\
& Other (Gifts or & 8 & 3.7 & 1 & 0.5 \\
& Remittances) & & & & \\
\hline
\end{tabular}

Table 5. Chi square tests of association results.

\begin{tabular}{llllllll}
\hline Test & Gender & $\begin{array}{l}\text { Age } \\
\text { Group }\end{array}$ & $\begin{array}{l}\text { Marital } \\
\text { Status }\end{array}$ & $\begin{array}{l}\text { Highest Edu. } \\
\text { Qualification }\end{array}$ & $\begin{array}{l}\text { Household } \\
\text { Size }\end{array}$ & $\begin{array}{l}\text { Income } \\
\text { Group }\end{array}$ & Occupation \\
\hline Pearson Chi-Square & 2.738 & 3.250 & 13.282 & 14.504 & 0.452 & 5.025 & 13.476 \\
Asymp. Sig. (2-sided) & 0.098 & 0.197 & $0.010^{*}$ & 0.013 & 0.501 & 0.170 & 0.019 \\
\hline
\end{tabular}

* The expected count for more than $25 \%$ of the cells was less than 5 , which means that the Chi-square test was invalid.

Relationship between willingness to pay for irrigation water and demographic variables

Table 6 shows cross-tabulation results for the relationship between willingness to pay for irrigation water and gender, age group, marital status, highest education qualification, income group, household size, occupation and quantity of water collected.

Table 6. Relationship between willingness to pay for irrigation water and demographic variables.

\begin{tabular}{|c|c|c|c|c|c|}
\hline \multirow{3}{*}{$\begin{array}{l}\text { Demographic } \\
\text { Characteristic }\end{array}$} & \multirow[t]{3}{*}{ Variable } & \multicolumn{4}{|c|}{ Amount Willing to Pay for Irrigation Water (USD) } \\
\hline & & \multicolumn{2}{|c|}{0 up to 0.66} & \multicolumn{2}{|c|}{0.67 up to 15.38} \\
\hline & & Count & $\%$ of Total & Count & $\%$ of Total \\
\hline \multirow[t]{2}{*}{ Gender } & Male & 73 & 33.3 & 87 & 39.7 \\
\hline & Female & 42 & 19.2 & 17 & 7.8 \\
\hline \multirow[t]{3}{*}{ Age Group } & 16 to 21 years & 2 & 0.9 & 3 & 1.4 \\
\hline & 22 to 59 years & 76 & 35.7 & 92 & 43.2 \\
\hline & 60 and above & 32 & 15.0 & 8 & 3.8 \\
\hline
\end{tabular}


Table 6. Cont.

\begin{tabular}{|c|c|c|c|c|c|}
\hline \multirow{3}{*}{$\begin{array}{l}\text { Demographic } \\
\text { Characteristic }\end{array}$} & \multirow[t]{3}{*}{ Variable } & \multicolumn{4}{|c|}{ Amount Willing to Pay for Irrigation Water (USD) } \\
\hline & & \multicolumn{2}{|c|}{0 up to 0.66} & \multicolumn{2}{|c|}{0.67 up to 15.38} \\
\hline & & Count & $\%$ of Total & Count & $\%$ of Total \\
\hline \multirow[t]{5}{*}{ Marital Status } & Single & 2 & 0.9 & 2 & 0.9 \\
\hline & Married & 74 & 33.8 & 92 & 42.0 \\
\hline & Separated & 4 & 1.8 & 0 & 0.0 \\
\hline & Divorced & 10 & 4.6 & 2 & 0.9 \\
\hline & Widowed & 25 & 11.4 & 8 & 3.7 \\
\hline Highest Education & Illiterate & 32 & 14.6 & 15 & 6.8 \\
\hline \multirow[t]{5}{*}{ Qualification } & Read \& write & 52 & 23.7 & 45 & 20.5 \\
\hline & PSLCE (Yr8) & 18 & 8.2 & 18 & 8.2 \\
\hline & JCE (Yr10) & 7 & 3.2 & 12 & 5.5 \\
\hline & MSCE (Yr12) & 5 & 2.3 & 14 & 6.4 \\
\hline & Tertiary & 1 & 0.5 & 0 & 0.0 \\
\hline \multirow[t]{2}{*}{ Household Size } & Less than 6 & 95 & 43.4 & 77 & 35.2 \\
\hline & More than 6 & 20 & 9.1 & 27 & 12.3 \\
\hline \multirow[t]{4}{*}{ Income Group } & 1 & 49 & 22.4 & 29 & 13.2 \\
\hline & 2 & 15 & 6.8 & 19 & 8.7 \\
\hline & 3 & 37 & 16.9 & 31 & 14.2 \\
\hline & 4 & 14 & 6.4 & 25 & 11.4 \\
\hline \multirow[t]{6}{*}{ Occupation } & Subsistence Farming & 38 & 17.4 & 45 & 20.5 \\
\hline & Commercial Farming & 6 & 2.7 & 12 & 5.5 \\
\hline & Small Business & 32 & 14.6 & 26 & 11.9 \\
\hline & Employed & 7 & 3.2 & 8 & 3.7 \\
\hline & Casual Labour & 24 & 11.0 & 12 & 5.5 \\
\hline & Other (Gifts or Remittances) & 8 & 3.7 & 1 & 0.5 \\
\hline
\end{tabular}

The Chi square test of association summarised in Table 7 showed that there is a relationship between gender, income group, occupation and willingness to pay for irrigation water $($ Chi-square $=11.294, p$-value $=$ 0.001, Chi-square $=8.700, p$-value $=0.034$, and Chi-square $=12.200$, $p$-value $=0.032$ respectively). However, the Chi square test of association showed that there were no significant associations between willingness to pay and age group, marital status, highest education qualification and income group because the minimum cell count assumption was not satisfied although the p-value were less than 0.05.

Table 7. Chi square tests of association results.

\begin{tabular}{llllllll}
\hline Test & Gender & Age Group & $\begin{array}{l}\text { Marital } \\
\text { Status }\end{array}$ & $\begin{array}{l}\text { Highest Edu. } \\
\text { Qualification }\end{array}$ & $\begin{array}{l}\text { Household } \\
\text { Size }\end{array}$ & $\begin{array}{l}\text { Income } \\
\text { Group }\end{array}$ & Occupation \\
\hline Pearson Chi-Square & 11.294 & 15.911 & 19.540 & 12.713 & 2.380 & 8.700 & 12.200 \\
Asymp. Sig. (2-sided) & 0.001 & $0.000^{*}$ & $0.001 *$ & 0.026 & 0.123 & 0.034 & 0.032 \\
\hline
\end{tabular}

\footnotetext{
* The expected count for more than $25 \%$ of the cells had a count less than 5 , which means that the Chi-square test was invalid.
} 
A logistic regression was also performed to assess the effects of the independent variables on the likelihood that individuals were willing to pay $\$ 0.67$ or more for irrigation water (the dependent variable). Age, household size and occupation had a significant effect on willingness to pay for irrigation water (Chi-square $=25.157, p$-value $<0.000$ ). The model only explained $11.3 \%$ of the variation in willing to pay and correctly classified $63.8 \%$ of the cases. These results show that even though age had a significant effect on willingness to pay for water, there were no significant differences among the age categories. Furthermore, an increase in the number of individuals in a household was associated with an increase in the likelihood of willingness to pay between $\$ 0.67$ and $\$ 15.38$ for irrigation water. Furthermore, the respondents who were involved in commercial farming had the same likelihood of paying for irrigation water as the respondents who were involved in subsistence farming. Those who were employed were 0.134 times more likely to pay for irrigation water.

\section{Energy Access}

\section{Energy types}

The percentages of households that reported any use of each of a number of energy sources are summarised in Figure 11.

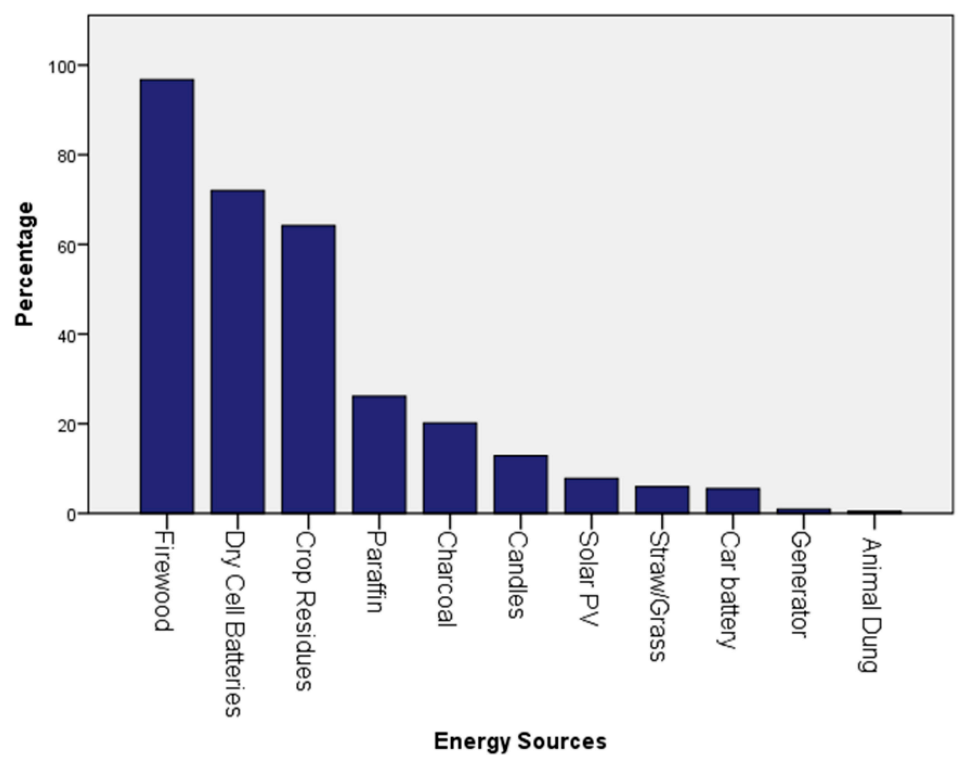

Figure 11. Percentages of households who reported any use of each energy source.

The results show that the most commonly used energy sources in Chiradzulu were firewood, which was used by 213 households (97\%); non-rechargeable dry cell batteries, which were used by 158 households (72\%); and crop residues, which were used by 140 households (64\%). Animal dung and diesel generators are rarely used, and although the grid lines passed through some of the surveyed areas no villages were connected to the grid. Overall, only 32 households (14.6\%) reported that 
they were satisfied with their current sources of energy, the rest indicated dissatisfaction for the reasons shown in Table 8.

Table 8. Reasons for dissatisfaction with current source of energy.

\begin{tabular}{ll}
\hline Reason for Dissatisfaction & Amount (Percentage) \\
\hline Non-rechargeable Dry Cell batteries are expensive & $131(59.8 \%)$ \\
Scarcity of firewood & $123(56.2 \%)$ \\
Lack of optional sources of energy & $26(11.9 \%)$ \\
Long distance to phone charging & $20(9.1 \%)$ \\
Paraffin is expensive & $16(7.3 \%)$ \\
Insufficient power from solar PV & $8(3.7 \%)$ \\
Candles are expensive & $5(2.3 \%)$ \\
\hline
\end{tabular}

\section{Cost of energy}

The cost of energy for the households is summarised in Table 9, which shows the median costs per household per month of US $\$ 0.28$, US $\$ 0.55$, US $\$ 0.80$, and US $\$ 2.77$ for mobile phone charging, lighting, radio and firewood, respectively. The cost of water is also included in the table for comparison and shows that water is the service for which households pay the least.

Table 9. Cost of energy per household per month.

\begin{tabular}{lllllll}
\hline Variable & $N$ & Mean & Median & SD & Minimum & Maximum \\
\hline Monthly Income (US\$) & 214 & 20.01 & 10.81 & 24.81 & 0.24 & 140.80 \\
Expenditure (US\$) & 214 & 13.47 & 9.71 & 12.92 & 0.35 & 97.09 \\
Cost of Firewood (US\$) & 65 & 3.49 & 2.77 & 2.47 & 0.21 & 13.87 \\
Firewood Roundtrip (Hrs) & 157 & 2.31 & 2.00 & 1.65 & 0.20 & 10.00 \\
Cost of Lighting Energy (US\$) & 206 & 0.72 & 0.55 & 0.78 & 0.28 & 5.55 \\
Current Cost for Phone Charging (US\$) & 115 & 0.41 & 0.28 & 0.29 & 0.06 & 2.08 \\
Distance to Charging Place (km) & 119 & 3.28 & 2.50 & 2.78 & 0.10 & 20.00 \\
Cost of Batteries for Radio (US\$) & 88 & 1.07 & 0.80 & 0.91 & 0.14 & 6.24 \\
Cost of Water (US\$) & 201 & 0.29 & 0.19 & 0.20 & 0.04 & 0.96 \\
\hline
\end{tabular}

Main energy source for cooking

Biomass was used for cooking by $100 \%$ of households in the rural areas of Chiradzulu, and was used in the form of firewood ( $n=204$, or 93\%), crop residues $(n=13$, or $6 \%)$ and charcoal $(n=2$, or $1 \%)$. The majority of households ( $n=150$, or $69 \%$ ) collected their firewood from the forests and gardens, 46 (21\%) purchased firewood, and the rest 14 (6\%) collected from their own woodlots. According to participants in the FGDs and observation, firewood was mostly used in open fires. Participants reported that firewood was mainly collected by women and girls and that it was getting scarcer, which made it necessary to travel long distances to collect it, with an average of $2.3 \mathrm{~h}$ and up to a maximum of $11 \mathrm{~h}$ per 
round trip. Observations showed that deforestation was visibly evident in the district.

\section{Main energy source for lighting}

The main energy source for lighting was light emitting diode (LED) torches powered by non-rechargeable dry cell batteries, which were used by 148 households (67.8\%). Forty-three households (19.63\%) used paraffin lamps, and 15 households (6.85\%) used solar PV lamps. The younger generation preferred torches for lighting, although the older generation still preferred the use of paraffin. The "other" category of households ( $n=13$, or 5.94\%) used candles, biomass (i.e., straw, grass, firewood), solar home systems and rechargeable car batteries. The non-rechargeable dry cell batteries used in torches were also the main source of energy for radios. However, households sometimes forewent lighting and listening to the radio because of the cost of batteries. Participants in the FGDs indicated that they did not have proper disposal methods for the non-rechargeable batteries.

\section{Main energy source for mobile phone charging}

Of the 127 households (58\%) that owned mobile phones, the following methods of phone charging were reported (as a percentage of all households): (1) 113 (51.6\%) charged elsewhere for a fee; (2) 11 (5\%) owned and used solar PV systems; and (3) 5 (2.3\%) charged elsewhere for no fee. The households that took their phones elsewhere for charging had to travel distances of up to $20 \mathrm{~km}$, and in the rainy season distances became longer because some roads became impassable. FGD participants complained that because of congestion at the charging place, sometimes phones were not fully charged and also that car batteries and inverters, which some business people used, had damaging effects on their phones.

\section{Knowledge on renewable energy sources}

The respondents were aware of the following renewable energy sources: (1) solar PV ( $n=203$, or 92.7\%); (2) hydro ( $n=184$, or $84 \%$ ); (3) wind ( $n=35$ or $16 \%)$; and (4) biogas ( $n=16$, or $7.3 \%$ ). Popular sources of information on renewable energy sources were radio $(n=157$, or $71.7 \%$ ) followed by word of mouth ( $n=153$, or $69.9 \%$ ). The less popular methods of dissemination were demonstration projects ( $n=49$, or $22.4 \%$ ), village meetings ( $n=27$, or $12.3 \%$ ), at school ( $n=11$, or $5 \%$ ), at religious places ( $n=8$, or $3.7 \%$ ), and TV ( $n=3$, or $1.4 \%$ ). If electricity were to be available, then the households aspired to a variety of income generating activities such as mobile phone and car battery charging, salons, barbershops, the sale of miscellaneous cold or frozen drinks and foods, chicken and egg production, and baking, among others. The village heads wished for maize milling machines, irrigation systems, grid electricity, and solar home systems, among other things. The households were 
willing to be trained in business and farm practices, and to have access to loans not necessarily in cash but that could be provided in goods such as individual solar home systems, community SPWP systems, food, and school fees assistance.

\section{DISCUSSION}

This research seeks to define the water and energy needs in the rural areas of Malawi within the socio-economic context of the region, and to develop a new framework for delivering cost-effective PV-based water and energy services. The results reveal some important risks, barriers and opportunities, which need to be considered when seeking to implement such a framework. Of these, the appropriate design and operation of new innovative business models in such low-income settings is of critical importance, especially if independence from externally subsidised or grant-aided water and energy services is the goal. In this context, provision of potable water services for household needs should be viewed in conjunction with synergies for parallel needs, including (a) additional water services such as irrigation and (b) sustainable, cost-effective community energy services.

Given the high dependence of households on agriculture in our case study area of Chiradzulu, an opportunity for improving irrigation practices using PV-powered water extraction infrastructure is evident. Currently, subsistence farming households use traditional irrigation methods such as watering cans or treadle pumps (both of which are physically exhausting and time consuming. Thus, irrigation systems designed for small or medium-sized individual subsistence farmers [24,25], potentially based on exemplars from nearby Kenya [59], could be of particular benefit.

In terms of risks associated with developing such a water services strategy, those related to evidence of the community's 'willingness to pay' are significant. For example, a wide range of variables can influence empirical evidence of willingness to pay [73], which need to be explored in further work around suitable business models. Such variables as respondents' age, household size and occupation of the household head have been shown to be significant factors in determining willingness to pay for water services. For agriculture water, factors such as farm size, distance to market, type of crop and type of water source, among others $[64,65]$ have also been shown to be significant in previous studies. This is particularly relevant given our finding that households were apparently willing to pay more for irrigation water than for drinking water (medians of US $\$ 0.96$ vs. US $\$ 0.38$ respectively). This finding could be related to the perceived financial value of agriculture water in terms of farm yield increases, a result supported by previous work in Kenya [66]. Alternatively, another influencing factor could be that males (comprising the majority of survey respondents) do not perceive significant value 
associated with the time spent collecting drinking water-an activity which is predominantly the responsibility of females or children.

Of key economic relevance is the generally low level of household disposable income within the case study area. Given that $75 \%$ of households have an income of less than US\$1 per household per day, any significant increase in the cost of energy and water service provision would be problematic. However, our analysis shows a very high proportion of household income is currently spent on energy services, with each household paying on average $40 \%$ of their income for energy needs, a finding consistent with other studies [67]. Our work also found that households would be interested in paying for solar-PV electricity if it were available at competitive cost. Given that the community's current energy services are generally more expensive than electricity generated from PV systems (for example kerosene or candles used for lighting, both of which have a negative impact on indoor air quality) [68], a transition to PV-derived energy may actually help alleviate energy cost barriers to implementation, whilst both reducing the ongoing incidence of household "fuel poverty" and improving health issues related to currently poor indoor air quality.

For such high value household energy services as lighting, our research provides some important insights into potential technical and business models for water and energy co-provision. For example, replacing kerosene and non-rechargeable battery energy sources with rechargeable lamps is possible using relatively small PV capacity additions to infrastructure installed primarily for high power water pumping services. This opens up the possibility of cost-effective cross subsidisation of water services without reliance on external sources of funding, especially given that solar PV sources have been shown in some settings to decrease lighting energy costs for households by up to $87.5 \%$ [69].

Additional opportunities for cross-subsidisation of clean water services include leveraging $\mathrm{PV}$-water infrastructure to provide more cost-effective and convenient mobile phone charging services. The majority of households in our case study reported taking their phones elsewhere for charging, in some cases up to $20 \mathrm{~km}$ away. Thus, the prospect of improving digital communication by such PV-water platform leveraging is very attractive. This is especially relevant in terms of economic development benefits, given the current deficits in reliable postal services, landline telephones or banks. Improving the quality of mobile phone services can help mitigate these issues and underpin economic activity in rural areas, for example by enabling rapid agricultural transactions, monitoring health care, and facilitating digital financial services [70-72]. The case for leveraging water-focused PV infrastructure for multi-faceted economic development impacts thus becomes compelling when the benefits accruing from improved lighting, mobile phone charging and other power services (such as cooking) [73] 
are considered. In this latter case, our study shows that biomass (i.e., firewood, crop residues and charcoal) remains the primary source of cooking energy, a finding that is consistent with other studies [49,50,61]. Its availability is reducing as deforestation increases, and excessive distances are travelled (and time spent) in collecting fuel. Lessons drawn from recent work on PV-powered cooking services in similar contexts could prove valuable in this regard [74].

Over the longer term, the links between improved water and energy services and parallel initiatives to improve the region's socio-economic situation should be considered, with apparent co-synergies that could support such development evaluated in depth in future work. For example, our results indicate that collecting water affects school attendance in a fifth of households, with children being either late or absent from school because of water collection. In terms of gender disparities, our evidence shows that the majority of women invest a considerable proportion of their time collecting water. Nearly two thirds of women and girls invest more than 30 min per trip, whilst $60 \%$ of households collect water more than four times per day, a finding consistent with previous work [17]. In our particular case, the data shows that excessive time spent collecting water is mainly due to queuing and low water yield rather than distance travelled. Thus, systems designed to include multiple water sources with reasonable yields should reduce time spent collecting water. In terms of longer term cultural change, the factors influencing the time spent by women (rather than men) collecting water may be difficult to address [75], but doing so could in future help minimise the opportunity costs associated with the time invested in water-fetching, especially given the importance of female involvement in wider community economic activities.

From the perspective of specific future PV/water-enabled opportunities, the high future value of this increased available time becomes apparent if education and skills development is considered. For example, womenfolk would have more time to invest in education related to important local economic activities. Skills thus developed could be focused on addressing water system technical risks, such as boreholes becoming non-functional due to the lack of skills or finance within the community to carry out repairs, a problem seen in previous work [76]. With increased and targeted government support, additional risks could be addressed and opportunities realised, such as the creation of adequate supply chains for equipment and spare parts, or the development of community expertise to effectively procure such goods and services from supply chains [9].

Finally, for longer term dissemination and replication of successful business models, a strategic focus on improving levels of educational qualifications in low-income communities have been shown to accelerate the uptake of new energy and water technologies, and reduce community opposition to such sustainable development initiatives [77,78], whilst 
evidence has shown that educational empowerment can also help increase community acceptance of sustainable services, especially if linked to improvement in farm productivity and efficiencies [78].

\section{CONCLUSIONS}

This research was carried out to clarify a framework for the provision of sustainable water and energy needs in rural areas of Malawi. The results indicate that:

- An integrated approach and co-development of water and energy services can leverage cost efficiencies related to PV capital infrastructure expenditure;

- Business models that include co-provision of water for both potable and agricultural purposes could address risks related to "willingness to pay" uncertainties;

- Potential profits arising from the provision of high-value energy services, (including for rechargeable lanterns and phone or radio charging), can offer internal 'cross-subsidy' opportunities for more costly water services;

- Empowerment of villagers (especially women) can support local innovation and entrepreneurship, and support the sustainable economic development of remote rural communities in Malawi.

\section{DATA AVAILABILITY}

The dataset of the study is available from the authors upon reasonable request.

\section{AUTHOR CONTRIBUTIONS}

EP developed the concept of this study under the supervision of PNR, and REB. EP supervised the collection of data. EP and AK analysed the data with input from PNR and REB. EP drafted the paper and PNR and REB critically revised the paper.

\section{CONFLICTS OF INTEREST}

Richard E. Blanchard is a guest editor for Journal of Sustainability Research. The rest of the authors declare that there is no conflict of interest.

\section{FUNDING}

Esther Phiri is a Commonwealth Scholar. The data collection phase was partly funded by The University of Malawi Research and Publications Committee. 


\section{ACKNOWLEDGMENTS}

We wish to acknowledge the assistance of Save Kumwenda, Kondwani Chidziwisano, Timothy Chadza and Khumbo Kalulu, research assistants, District Commissioner, household heads, village heads, and Health Surveillance Assistants during the data collection process.

\section{REFERENCES}

1. Hussey K, Pittock J. The Energy-Water Nexus: Managing the Links between Energy and Water for a Sustainable Future. Ecol Soc. 2012;17(1):31.

2. Bizikova L, Roy D, Swanson D, Venema HD, Mccandless M. The Water-Energy-Food Security Nexus: Towards a practical planning and decision-support framework for landscape investment and risk management. Winnipeg (Canada): International Institute for Sustainable Development; 2013. Available from: http://empoderamiento.info/biblioteca/ files/original/8e66ac686bf713f8c49a55d85db1e8fa.pdf. Accessed 2017 May 12.

3. GoM. Malawi Millenium Development Goals Endline Report. Lilongwe (Malawi): GoM; 2014. Available from: https://www.undp.org/content/dam/ malawi/docs/general/UNDP MW EDP MDG book final.pdf. Accessed 2019 Oct 3.

4. Harvey PA. Borehole sustainability in rural Africa: an analysis of routine field data. In: Proceedings of the 30th WEDC Conference; 2004 Oct 25-29; Vientiane, Lao PDR. Loughborough (UK): Loughborough University; 2004. Available from: https://dspace.lboro.ac.uk/dspace-jspui/handle/2134/2109. Accessed 2016 May 4.

5. Pritchard M, Mkandawire T, O'Neill JG. Biological, chemical and physical drinking water quality from shallow wells in Malawi: Case study of Blantyre, Chiradzulu and Mulanje. Phys Chem Earth Parts A/B/C. 2007;32(15-18):1167-77.

6. United Nations. The Millennium Development Goals Report 2013. New York (NY, US): United Nations; 2013. Available from: http://www.un.org/millenniumgoals/pdf/report-2013/mdg-report-2013-englis h.pdf. Accessed 2014 Dec 1.

7. SNV. Functionality: The challenge to sustain rural water supply services. The Hague (Netherlands): SNV; 2013.

8. Gutierrez E. Delivering pro-poor water and sanitation services: The technical and political challenges in Malawi and Zambia. Geoforum. 2007 Sep;38(5):886-900.

9. Harvey P. Poverty Reduction Strategies: opportunities and threats for sustainable rural water services in sub-Saharan Africa. Prog Dev Stud. 2008;8(1):115-28.

10. Lee C-C. Energy consumption and GDP in developing countries: A cointegrated panel analysis. Energy Econ. 2005;27(3):415-27.

11. WWAP. The United Nations World Water Development Report 2015: Water for a Sustainable World. Paris (France): UNESCO; 2015. 
12. Fewtrell L, Kaufmann RB, Kay D, Enanoria W, Haller L, Colford JM Jr. Water, sanitation, and hygiene interventions to reduce diarrhoea in less developed countries: a systematic review and meta-analysis. Lancet Infect Dis. 2005;5(1):42-52.

13. Graham JP, Hirai M, Kim S-S, Raina K, Robson E, Mashiri M. An Analysis of Water Collection Labor among Women and Children in 24 Sub-Saharan African Countries. PLoS One. 2016;11(6):e0155981. https://doi.org/10.1371/journal.pone.0155981

14. Howard G, Bartram J. Domestic water quantity, service level, and health. Geneva (Switzerland): World Health Organisation; 2003. Available from: http://cdrwww.who.int/entity/water sanitation health/diseases/WSH03.02.pdf. Accessed 2017 Jan 6.

15. Hunter PR, Wang X. A Systematic Review and Meta-Analysis of the Association between Self-Reported Diarrheal Disease and Distance from Home to Water Source. Am J Trop Med Hyg. 2010;83(3):582-4.

16. WHO \& UNICEF. Drinking Water Equity, Safety and Sustainability: Thematic report on drinking water 2011. New York (NY, US): UNICEF; 2011.

17. Blagbrough V. Looking back: The long-term impacts of water and sanitation projects. London (UK): WaterAid; 2001.

18. Sommer M, Ferron S, Cavill S, House S. Violence, gender and WASH: spurring action on a complex, under-documented and sensitive topic. Environ Urban. 2014;27(1):105-16.

19. Burney JA, Naylor RL. Smallholder Irrigation as a Poverty Alleviation Tool in Sub-Saharan Africa. World Dev. 2012;40(1):110-23.

20. Nkhata R. Does irrigation have an impact on food security and poverty: Evidence from Bwanje Valley Irrigation Scheme in Malawi. Lilongwe (Malawi): International Food Policy Research Institute; 2014. Available from: https://reliefweb.int/sites/reliefweb.int/files/resources/masspwp4.pdf. Accessed 2016 Jul 19.

21. You L, Ringler C, Wood-Sichra U, Robertson R, Wood S, Zhu T, et al. What is the irrigation potential for Africa? A combined biophysical and socioeconomic approach. Food Policy. 2011;36(6):770-82.

22. Coulibaly YJ, Gbetibouo AG, Kundhlande G, Sileshi WG, Beedy LT. Responding to Crop Failure: Understanding Farmers' Coping Strategies in Southern Malawi. Sustainability. 2015;7:1620-36.

23. SNV. Functionality: The challenge to sustain rural water supply services. The Hague (Netherlands): SNV; 2013. Available from: http://www.ruralwater-supply.net/ ressources/documents/default/1-600-2-1408015494.pdf. Accessed 2017 Jul 23.

24. Kamwamba-Mtethiwa J, Namara R, De Fraiture C, Mangisoni J, Owusu E. Treadle Pump Irrigation in Malawi: Adoption, Gender, and Benefits. Irrig Drain. 2012;61(5):583-95.

25. MacDonald AM, Bonsor HC, Dochartaigh BÉÓ, Taylor RG. Quantitative maps of groundwater resources in Africa. Environ Res Lett. 2012;7(2):024009.

26. Gamula GET, Hui L, Peng W. Development of Renewable Energy Technologies in Malawi. Int J Renew Energy Technol Res. 2013;2(2):44-52. 
27. Al-Smairan M. Application of photovoltaic array for pumping water as an alternative to diesel engines in Jordan Badia, Tall Hassan station: Case study. Renew Sustain Energy Rev. 2012;16(7):4500-7.

28. Chidanti-Malunga JF. Wetland Farming and Small-Scale Informal Irrigation in Malawi: The Case of Shire Valley. PhD Thesis. Bedford (UK): Cranfield University; 2009.

29. Kamwamba-Mtethiwa JT. Sustainable irrigation development: The adoption of small-scale pumped irrigation in Malawi [dissertation]. Bedford (UK): Cranfield University; 2016.

30. United Nations. Energy for a Sustainable Future. New York (NY, US): United Nations; 2010.

31. Chandel SS, Nagaraju NM, Chandel R. Review of solar photovoltaic water pumping system technology for irrigation and community drinking water supplies. Renew Sustain Energy Rev. 2015;49:1084-99.

32. Calow R, MacDonald A. What will climate change mean for groundwater supply in Africa? Groundwater. 2009;48(2):246-56.

33. MacDonald A, Bonsor H, Calow R, Taylor R, Lapworth D, Maurice L, et al. Groundwater resilience to climate change in Africa. Nottingham (UK): British Geological Survey; 2011. British Geological Survey Open Report, OR/11/031.

34. Bonsor H, MacDonald A, Calow R. Potential Impact of Climate Change on Improved and Unimproved Water Supplies in Africa. RSC Issues Environ Sci Technol. 2010;31:25-40.

35. Mohammed Wazed S, Hughes BR, O’Connor D, Kaiser Calautit J. A review of sustainable solar irrigation systems for Sub-Saharan Africa. Renew Sustain Energy Rev. 2018; 81:1206-25.

36. Sontake VC, Kalamkar VR. Solar photovoltaic water pumping system-A comprehensive review. Renew Sustain Energy Rev. 2016;59:1038-67.

37. Ahmad J, Goldar B, Misra S, Jakariya M, Golder BN, Misra S, et al. Willingness to pay for arsenic-free, safe drinking water in Bangladesh. Dhaka (Bangladesh): World Bank Water and Sanitation Program-South Asia; 2003. Available from: http://www.ircwash.org/sites/default/files/Ahmad-2003Fighting.pdf. Accessed 2016 Dec 19

38. The World Bank. The Demand for Water in Rural Areas: Determinants and Policy Implications. World Bank Res Obs. 1993;8(1):47-70.

39. Taylor H, Ebdon J, Phillips R, Chavula G, Kapudzama O. Assessment of Drinking Water Quality for Low-cost Water Options in Rural Malawi. Brighton (UK): University of Brighton; 2012.

40. Chavula GMS. Malawi. In: Pavelic P, Giordano M, Keraita B, Ramesh V, Rao T, editors. Groundwater availability and use in Sub-Saharan Africa: a review of 15 countries. Colombo (Sri Lanka): International Water Management Institute; 2012. p. 78-90. Available from: https://ideas.repec.org/p/iwt/bosers/h046186.html. Accessed 2016 May 24.

41. Mapoma HWT, Xie X. Basement and alluvial aquifers of Malawi: An overview of groundwater quality and policies. Afr J Environ Sci Technol. 2014;8(3):190-202. 
42. Taulo S, Mkakosya R, Kululanga G. Microbiological quality of water, associated management practices and risks at source, transport and storage points in a rural community of Lungwena, Malawi. Afr J Microbiol Res. 2008;(2):131-7.

43. Masangwi SJ, Morse TD, Ferguson NS, Zawdie G, Grimason AM, Namangale JJ. Behavioural and environmental determinants of childhood diarrhoea in Chikwawa, Malawi. Desalination. 2009;248(1-3):684-91.

44. Furey SG. Handpumps: where now? A sythesis of online discussions. St Gallen (Switzerland): Rural Water Supply Network/Skat Foundation; 2014. Available from: http://www.rural-water-supply.net/ ressources/documents/ default/1-614-2-1409669801.pdf. Accessed 2017 Apr 27.

45. Baumann E, Furey S. How Three Handpumps Revolutionised Rural Water Supplies. A brief history of the India Mark II/III, Afridev and the Zimbabwe Bush Pump. St Gallen (Switzerland): SKAT, RWSN; 2013. Available from: http://www.rural-water-supply.net/_ressources/documents/default/1-475-2-1 363951079.pdf. Accessed 2017 May 11.

46. Foster T. Predictors of sustainability for community-managed handpumps in sub-Saharan Africa: evidence from Liberia, Sierra Leone, and Uganda. Environ Sci Technol. 2013;47(21):12037-46.

47. Harvey PA, Reed RA. Community-managed water supplies in Africa: sustainable or dispensable? Community Dev J. 2006;42(3):365-78.

48. Chowns EEE. The political economy of community management: a study of factors influencing sustainability in Malawi's rural water supply sector [dissertation]. Birmingham (UK): University of Birmingham; 2014. Available from: http://etheses.bham.ac.uk/5014/2/Decl IS Chowns.pdf. Accessed 2016 May 4.

49. National Statistical Office, ICF. Malawi Demographic and Health Survey 2015-16. Zomba (Malawi): National Statistical Office (NSO); Rockville (MA, US): ICF International; 2017.

50. National Statistical Office. Malawi Demographic and Health Survey. Zomba (Malawi): National Statistical Office; 2011. Available from: http://dhsprogram.com/pubs/pdf/FR247/FR247.pdf. Accessed 2014 Dec 1.

51. Collings S. Phone charging micro-businesses in Tanzania and Uganda. London (UK): GVEP International. 2011. Available from: https://yoursri.com/users/4abdbf22f6f89886b87cbf910faaff9a/fbbb2bbbf29ab 097bb79c75e59fba08d/@@download/fs/Phone Charging Micro.pdf. Accessed 2017 Apr 24.

52. Almeida R, Brito M. A review of technical options for solar charging stations in Asia and Africa. AIMS Energy. 2015;3(3):428-49.

53. Central Intelligence Agency. The World Factbook. Washington, D.C. (US): CIA; 2017. Available from: https://www.cia.gov/library/publications/resources/ the-world-factbook/geos/mi.html. Accessed 2017 Feb 27.

54. The World Bank. Malawi: Country at a Glance. 2015. Available from: http://www.worldbank.org/en/country/malawi. Accessed 2016 Aug 9.

55. Phiri A. District Commissioner. Personal Communication. 2015 Jul 29.

56. Babbie ER. The practice of social research. 14th ed. Boston (US): Cengage 
Learning; 2016.

57. Bryman A. Integrating quantitative and qualitative research: how is it done? Qual Res. 2006;6(1):97-113. http://qrj.sagepub.com/cgi/doi/10.1177/ 1468794106058877

58. Laws S, Marcus C, Harper R. Research for Development A Practical Guide. New Delhi (India): SAGE Publications; 2003.

59. Hoshaw-Woodard S. Description and comparison of the methods of cluster sampling and lot quality assurance sampling to assess immunization coverage. Geneva (Switzerland): WHO; 2001.

60. Czaja R, Blair J, Blair E. Designing surveys: a guide to decisions and procedures. 3rd ed. Los Angeles (US): SAGE; 2014.

61. Adkins E, Oppelstrup K, Modi V. Rural household energy consumption in the millenium villages in Sub-Saharan Africa. Energy Sustain Dev. 2012;16:249-59.

62. National Statistical Office. Malawi Third Integrated Household Survey (IHS3). Zomba (Malawi): National Statistical Office; 2012. Available from: http://siteresources.worldbank.org/INTLSMS/Resources/3358986-1233781970 982/5800988-1271185595871/IHS3.BID.FINAL.pdf. Accessed 2014 Dec 1.

63. WHO/UNICEF. Core questions on drinking-water and sanitation for household surveys. Geneva (Switzerland): WHO; 2006. Available from: http://www.who.int/water sanitation health/monitoring/oms brochure core questionsfinal24608.pdf. Accessed 2016 Aug 9.

64. Tang Z, Nan Z, Liu J. The Willingness to Pay for irrigation water: A Case study in Northwest China. Glob Nest J. 2013;15(1):76-84.

65. Namyenya A, Sserunkuuma D, Bagamba F. Willingness to pay for irrigation water and its determinants among rice farmers at Doho Rice Irrigation Scheme (DRIS) in Uganda. J Dev Agric Econ. 2014;6(8):345-55.

66. Sharma S. Willingness To Pay for Drinking Water Supply and Sanitation. 1997.

67. Gradl C, Knobloch C. Energize the BoP! Energy Business Model Generator for Low-Income Markets : A Practitioner's Guide. Berlin (Germany): Endeva UG; 2011. Available from: https://www.giz.de/Wirtschaft/de/downloads/ giz2011-0617en-endeva.pdf. Accessed 2017 Aug 8.

68. Fullerton DG, Semple S, Kalambo F, Suseno A, Malamba R, Henderson G, et al. Biomass fuel use and indoor air pollution in homes in Malawi. Occup Environ Med. 2009;66(11):777-83.

69. Adkins E, Eapen S, Kaluwile F, Nair G, Modi V. Off-grid energy services for the poor: Introducing LED lighting in the Millennium Villages Project in Malawi. Energy Policy. 2010;38(2):1087-97.

70. Aker JC, Mbiti IM. Mobile Phones and Economic Development in Africa. J Econ Perspect. 2010;24(3):207-32.

71. Hampshire K, Porter G, Owusu SA, Mariwah S, Abane A, Robson E, et al. Informal m-health: How are young people using mobile phones to bridge healthcare gaps in Sub-Saharan Africa? Soc Sci Med. 2015;142:90-9.

72. World Bank. World Development Report 2014: Risk and Opportunity-Managing Risk for Development. Washington, DC (US): World 
Bank; 2013.

73. O’shaughnessy SM, Deasy MJ, Doyle JV, Robinson AJ. Field Trial Testing of an Electricity-Producing Portable Biomass Cooking Stove in Rural Malawi. Energy Sustain Dev. 2014;20(1):1-10.

74. Batchelor S, Brown E, Scott N, Leary J. Two Birds, One Stone-Reframing Cooking Energy Policies in Africa and Asia. Energies. 2019;12(9):1591.

75. Van-Houweling E. “A Good Wife Brings Her Husband Bath Water”: Gender Roles and Water Practices in Nampula, Mozambique. Soc Nat Resour. 2016;29(9):1065-78.

76. Chisenga B. Project maintenance: the case of rural drinking-water in Malawi [dissertation]. Salford (UK): University of Salford; 2014. Available from: http://usir.salford.ac.uk/id/eprint/32859. Accessed 2017 Apr 14.

77. Mohammed YS, Mustafa MW, Bashir N. Status of renewable energy consumption and developmental challenges in Sub-Sahara Africa. Renew Sustain Energy Rev. 2013;27:453-63.

78. Tchale H. The efficiency of smallholder agriculture in Malawi. AFJARE. 2009;3(2):101-21.

How to cite this article:

Phiri E, Kasambara A, Rowley PN, Blanchard RE. Energy and Water Needs Analysis: Towards Solar Photovoltaic Water Pumping in Rural Areas of Malawi. J Sustain Res. 2020;2(2):e200013. https://doi.org/10.20900/jsr20200013 